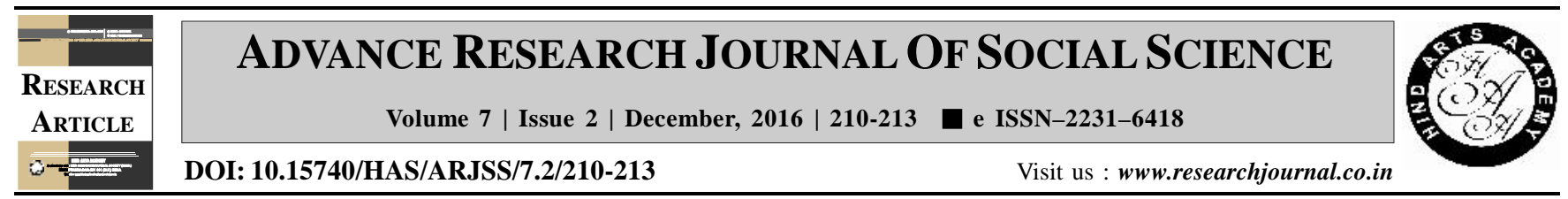

\title{
Awareness and adoption of pesticides by cotton growers
}

S.M. Borhude, V.V. Gohad* and Ashwini V. Surduse

Department of Extension Education, Shri Shivaji Agriculture College, AMRAVATI (M.S.) INDIA

\section{ARTICLE INFO :}

$\begin{array}{lll}\text { Received } & : & 23.07 .2016 \\ \text { Revised } & : & 23.10 .2016 \\ \text { Accepted } & : & 05.11 .2016\end{array}$

KEY WORDS :

Awareness, Adoption, Cotton growers

\section{HOW TO CITE THIS ARTICLE :}

Borhude, S.M., Gohad, V.V. and Surduse, Ashwini V. (2016). Awareness and adoption of pesticides by cotton growers. Adv. Res. J. Soc. Sci., 7 (2) : 210-213, DOI: 10.15740/HAS/ARJSS/7.2/210-

213.

*Author for correspondence

\begin{abstract}
The present study on awareness and adoption of pesticides by cotton growers was conducted in the year 2015-16 in Amravati district. Results obtained after analysis have been summarized as below. Findings of relational analysis revealed that age, education, land holding, farming experience and innovativeness were positive and significant correlated with awareness. Social participation had shown negative and significant correlation with awareness. Whereas risk orientation had shown nonsignificant correlation with awareness. However, the variables like age, education, farming experience, social participation, innovativeness and risk orientation had shown positive and significant correlation with adoption. Land holding had shown nonsignificant correlation with adoption.
\end{abstract}

